\title{
BEBERAPA ASPEK BIOLOGI IKAN OSKAR (Amphilophus citrinellus) DI WADUK IR. H. DJUANDA, JATILUHUR, JAWA BARAT
}

\author{
Sri Endah Purnamaningtyas dan Didik Wahju Hendro Tjahjo \\ Peneliti pada Balai Riset Pemulihan Sumber Daya Ikan, Jatiluhur-Purwakarta \\ Teregistrasi I tanggal: 6 Maret 2010; Diterima setelah perbaikan tanggal: 16 Maret 2010; \\ Disetujui terbit tanggal: 26 Maret 2010
}

\begin{abstract}
ABSTRAK
Ikan oskar (Amphilophus citrinellus) telah berkembang pesat di Waduk Ir. H. Djuanda, di mana keberadaannya dianggap meresahkan pada kebanyakan nelayan setempat. Ikan ini mempunyai nilai ekonomis yang rendah dan bersifat omnivora-karnivora, diduga perkembangan ikan ini mampu mendesak perkembangan jenis ikan lainnya di perairan tersebut. Tujuan dari penelitian ini adalah untuk mengetahui beberapa aspek biologi ikan oskar, meliputi pola kebiasaan pakan ikan, tingkat kematangan gonad, dan fekunditas yang dilakukan di Waduk Ir. H. Djuanda, Jatiluhur. Penelitian ini dilakukan pada bulan Maret, Juni, Agustus, Oktober, dan Desember 2006. Pengambilan contoh ikan menggunakan gillnet percobaan dengan ukuran mata jaring $1 ; 1,5 ; 2 ; 2,5 ; 3 ; 3,5$; dan 4 inci. Ikan oskar di waduk Ir. H. Djuanda merupakan ikan omnivora-karnivora yang memanfaatkan tumbuhan dan ikan sebagai pakan utamanya, larva serangga, dan fitoplankton sebagai pakan tambahan dan serangga, detritus dan zooplankton sebagai pakan pelengkap. Dari hasil pengamatan yang dilakukan didapatkan bahwa ikan oskar dapat berkembang dan bertelur sepanjang waktu dan fekunditasnya berkisar antara 1.595-3.567 butir.
\end{abstract}

KATAKUNCI: $\quad$ oskar (Amphilophus citrinellus), kebiasaan makan, fekunditas

ABSTRACT: $\quad$ Some of biology aspects of oskar (Amphilophus citrinellus) in Ir. H. Djuanda Reservoir, Jatiluhur West Java. By: Sri Endah Purnamaningtyas and Didik Wahju Hendro Tjahjo

Oskar (Amphilophus citrinellus) has rapidly expanded in Ir. H. Djuanda Reservoir, where existence of the fish is assumed fretting by local fishermen. This fish has low economic value and the character is omnivore-carnivore, development anticipation of this fish can depress growth of other fish species in the territorial water. This research aims to know some biology aspects of Oskar in Ir. H. Djuanda Reservoir, such as food habit, level of gonad maturity, and fecundity. This study is conducted in March, June, August, October, and December 2006. Gillnet with mesh size of 1; 1.5; 2; 2.5; 3; 3.5; and 4 inch were used for fish sampling. This species is categorised in omnovora-carnivora fish feed mainly on plant and small fish, while insect larvae and phytoplankton as additional food and insect, detritus and zooplankton as complement food. From this study resulted thet oskar could develop and spawn in a long season with fecundity range from 1,595-3,567 grains.

KEYWORDS: Oskar (Amphilophus citrinellus), food habit, fecundity

\section{PENDAHULUAN}

Ikan oskar adalah salah satu jenis ikan yang bukan asli Sungai Citarum maupun perairan Indonesia. Ikan ini merupakan ikan endemik di Costa Rica dan Nicaragua negara bagian Amerika Tengah dan sebagian Asia (Anonimus, 2007). Hidupnya sangat agresif di daerah teritorial. Ikan ini pada saat dewasa akan terlihat benjolan di kepalanya, mempunyai warna yang bagus seperti orange dan orange kemerahmerahan. Di Waduk Ir. H. Djuanda ikan ini disebut juga dengan nama red devil, sehingga ikan ini sangat cocok untuk dijadikan ikan hias air tawar
(Purnamaningtyas \& Tjahjo, 2007). Warna ikan tersebut tergantung dari kebiasaan makannya dan di mana ikan tersebut hidup. Ikan ini merupakan hasil tebaran (introduksi) yang tidak sengaja atau ikan yang lolos dari karamba jaring apung (Anonimus, 2006). Klasifikasi ikan oskar (Froese \& Pauly, 2006), sebagai berikut (Gambar 1):

Kingdom: Animalia Phillum: Chordata Kelas: Actinoptergii Ordo: Perciformes Famili: Cichlidae Genus: Amphilophus 


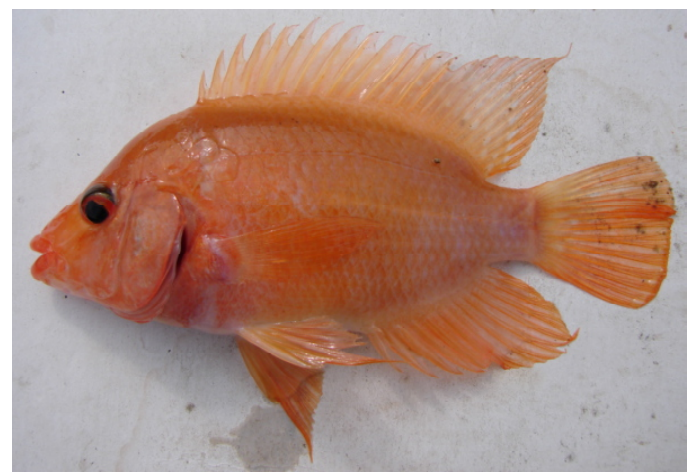

Gambar 1. Ikan oskar (Amphilophus citrinellus).

Figure 1. Oskar/red devil (Amphilophus citrinellus).

Menurut Anonimus (2007) ikan oskar sangat agresif, mempunyai panjang maksimum antara 25,0$37,5 \mathrm{~cm}$, hidup di daerah permukaan dan teritorial, dapat bertelur sepanjang waktu, membutuhkan $\mathrm{pH} 6$ 8 , alkalinitas $6-25 \mathrm{dH}$, dan suhu $23-27^{\circ} \mathrm{C}$. Apabila dewasa mempunyai morfologi yang berbeda antara jantan dan betina, mempunyai ukuran ekor lebih panjang daripada ukuran kepala.

Ikan ini telah berkembang pesat di Waduk Ir. $\mathrm{H}$. Djuanda, Cirata, Darma, dan Kedung Ombo, di mana keberadaanya dianggap meresahkan kebanyakan nelayan setempat. Berdasarkan pada informasi nelayan ikan oskar ini mempunyai nilai ekonomis yang rendah dan bersifat omnivora, sehingga perkembangan ikan ini mampu mendesak perkembangan jenis ikan lainnya yang ada di perairan tersebut.

Ikan ini merupakan ikan yang sangat mudah untuk beradaptasi dengan lingkungannya, sehingga mempunyai kemampuan yang tinggi dalam menyesuaikan fluktuasi kesediaan pakan yang ada. Fish Base (2006) dalam Froese \& Pauly (2006) mengatakan bahwa makanan yang mengandung karotin sangat berpengaruh terhadap kekuatan warna ikan, seperti warna kuning dan orange. Pakan merupakan prinsip dari mekanisme penyebaran secara ekologis, khususnya komunitas ikan air tawar (Gascon \& Legget dalam Macpherson, 1981).

Hasil tangkapan ikan oskar di Waduk Ir. H. Djuanda sangat dominan, yaitu sekitar $40,4 \%$ dari hasil tangkapan pada tahun 2003 dan 2004 dengan menggunakan gillnet percobaan, lebih banyak dibandingkan dengan hasil tangkapan lainnya seperti ikan bandeng (Channos channos), kongo (Parachromis managuensis), nila (Oreochromis niloticus), mas (Cyprinus carpio), jambal (Pangasionodon hypopthalmus), dan kebogerang (Mystus nigriceps) (Kartamihardja, 2007). Demikian juga menurut laporan hasil akhir penelitian tahun 2006 dan 2007 Loka Riset Pemacuan Stok Ikan, ikan oskar menempati urutan pertama hasil tangkapan dengan menggunakan gillnet.

Sedikitnya informasi mengenai ikan oskar ini, sehingga mendorong penulis untuk melakukan suatu penelitian mengenai beberapa aspek bologi ikan oskar di Waduk Ir. H. Djuanda.

\section{BAHAN DAN METODE}

Penelitian ini dilakukan di Waduk Ir. H. Djuanda pada bulan Maret, Agustus, Oktober, dan Desember 2006. Pengumpulan data dilakukan dengan menggunakan metode survei (stratified sampling method). Alat yang digunakan adalah gillnet dengan ukuran mata jaring jaring $1 ; 1,5 ; 2 ; 2,5 ; 3 ; 3,5$; dan 4 inci, yang dipasang pada jam lima sore dan diangkat jam enam pagi. Contoh ikan masing-masing diukur panjang bobot, diambil isi perut dan gonadnya kemudian diawetkan dengan formalin $4 \%$ dan kemudian diberi label. Pengamatan dilakukan di laboratorium Loka Riset Pemacuan Stok Ikan, Jatiluhur. Pengamatan gonad di laboratorium diambil pada bagian depan, tengah, dan belakang telur. Pada pengukuran panjang digunakan mistar dengan ketelitian $0,1 \mathrm{~mm}$, pengukuran bobot menggunakan timbangan analitik dengan ketelitian 0,0001 g, pengukuran diameter gonad menggunakan mikroskop mikro dengan menggunakan mikrometer dengan pembesaran $4 \times 10$ dengan skala $0,0025 \mu \mathrm{m}$.

Analisis kebiasaan pakan ikan dilakukan dengan menggunakan indeks of preponderance dari Natarajan \& Jhingran (1961) dalam Effendie (1979) yaitu:

$$
\mathrm{li}=\frac{\mathrm{V}_{\mathrm{i}} \times \mathrm{O}_{\mathrm{i}}}{\sum\left(\mathrm{V}_{\mathrm{i}} \times \mathrm{O}_{\mathrm{i}}\right)} \times 100 \%
$$


di mana:

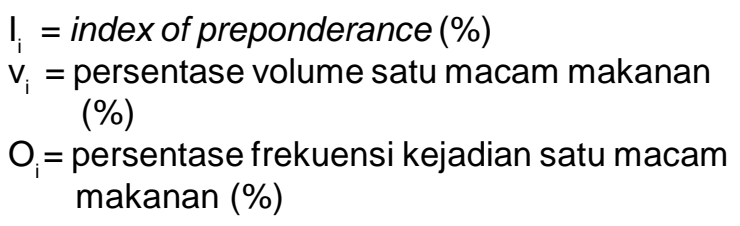

Untuk mengidentifikasi jenis makanan menggunakan buku identifikasi dari Edmonson (1959); Needham \& Needham (1963). Analisis indeks kematangan gonad dihitung berdasarkan pada Effendie (1979), yaitu:

$\mathrm{IKG}=\mathrm{Bg} / \mathrm{Bt} X 100 \%$ $(2$

di mana:

IKG = indeks kematangan gonad (\%)

$\mathrm{Bg}=$ bobot gonad $(\mathrm{g})$

$\mathrm{Bt}=$ bobot tubuh $(\mathrm{g})$

Data pengukuran panjang bobot ikan tersebut dianalisis untuk mengetahui sifat pertumbuhan ikan
(Effendie, 1979), apakah isometrik $(b=3)$ atau alometrik ( $\mathrm{b} \neq 3)$, dengan menggunakan rumus:

$W=a^{*} L^{b}$ (3

di mana:

$$
\begin{array}{ll}
\mathrm{W} & =\text { bobot ikan }(\mathrm{g}) \\
\mathrm{L} & =\text { panjang total }(\mathrm{cm}) \\
\mathrm{A} \text { dan } \mathrm{b} & =\text { kostanta }
\end{array}
$$

Penentuan tingkat kematangan gonad mengacu pada modifikasi dari Cassie dalam Effendie (1979) yang diklasifikasikan menjadi lima tingkatan terlihat pada Tabel 1. Analisis fekunditas dihitung berdasarkan pada metode gravimetrik dalam (Nikolsky, 1963), yaitu:

$$
\mathrm{X}: \mathrm{x}=\mathrm{B}: \mathrm{b}
$$

di mana:

$X=$ jumlah telur dalam gonad yang akan dicari

$X=$ jumlah telur sebagian kecil gonad

$\mathrm{B}=$ bobot seluruh gonad $(\mathrm{g})$

\begin{tabular}{|c|c|c|}
\hline Tingkat kematangan & Betina & Jantan \\
\hline 1 & $\begin{array}{l}\text { Ovari seperti benang, panjang sampai ke } \\
\text { depan rongga tubuh. Wama jemih. } \\
\text { Permukaanlicin. }\end{array}$ & $\begin{array}{l}\text { Testes seperti benang, lebih pendek (terbatas) } \\
\text { dan terlihat ujungnya di rongga tubuh. Wama } \\
\text { jernih. }\end{array}$ \\
\hline II & $\begin{array}{l}\text { Ukuran ovari lebih besar. Pewamaan lebih } \\
\text { gelap kekuning-kuningan. Telur belum terlihat } \\
\text { jelas dengan mata. }\end{array}$ & $\begin{array}{l}\text { Ukuran testes lebih besar. Pewamaan puth } \\
\text { sepert susu. Bentuk lebih jelas dari pada } \\
\text { tingkatl. }\end{array}$ \\
\hline III & $\begin{array}{l}\text { Ovar berwama kuning. Secara morpologi, } \\
\text { telur mulai kelihatan butirnya dengan mata. }\end{array}$ & $\begin{array}{l}\text { Permukaan testes tampak bergerigi. Wama } \\
\text { makin puth, testes makin besar. Dalam } \\
\text { keadaan diawetkanmudah putus. }\end{array}$ \\
\hline IV & $\begin{array}{l}\text { Ovari makin besar, telur berwama kuning, } \\
\text { mudah dipisahkan. Butir minyak tidak } \\
\text { tampak, mengisi } 1 / 2-2 / 3 \text { rongga perut, usus } \\
\text { terdesak. }\end{array}$ & $\begin{array}{l}\text { Seperti pada tingkat III tampak lebih jelas. } \\
\text { Testes semakinpejal }\end{array}$ \\
\hline V & $\begin{array}{l}\text { Ovari berkerut, dinding tebal, butir telur sisa } \\
\text { terdapat di dekat pelepasan. Banyak telur } \\
\text { seperti pada tingkat II }\end{array}$ & $\begin{array}{l}\text { Testes bagian belakang kempis dan di bagian } \\
\text { dekat pelepasan masih berisi. }\end{array}$ \\
\hline
\end{tabular}

$\mathrm{b}=$ bobot sebagian gonad $(\mathrm{g})$

Tabel 1. Tingkat kematangan gonad

Table 1. Gonado stage

\section{HASIL DAN BAHASAN}

Ikan oskar merupakan ikan pemakan segala sehingga ikan tersebut dapat dengan mudah beradaptasi dengan lingkungannya dalam mencari makanan. Hal tersebut sesuai dengan pendapat Beckman (1962) mengatakan bahwa persaingan dalam hal makanan baik di antara spesies maupun di dalam spesies akan mengurangi tersedianya makanan, sehingga makanan yang diperlukan terbatas. Hal ini akan mengubah tingkat pertumbuhan dan hanya ikan-ikan yang kuat dalam persaingan tersebut yang akan tumbuh dengan baik.

\section{Kebiasaan Makan}

Batasan pengelompokan makanan adalah sebagai berikut kelompok makanan utama adalah makanan yang mempunyai nilai indeks preponderan lebih besar dari $25 \%$, makanan pelengkap merupakan kelompok makanan yang mempunyai nilai indeks preponderan lebih besar dari $5 \%$ sampai sama atau kurang dari 
$25 \%$, dan makanan tambahan merupakan kelompok makanan yang mempunyai nilai indeks preponderan sama atau kurang dari 5\%. Menurut Nikolsky (1963) makanan alami pada ikan terdiri atas makanan utama (makanan yang dimakan dan menempati sebagian besar isi usus ikan), makanan kedua (secondary food) (makanan yang kadang-kadang terdapat dalam usus ikan dalam jumlah yang sedikit), dan makanan pelengkap (makanan yang sangat jarang terdapat pada usus ikan, dan hanya dimakan jika makanan utama tidak ada).

Berdasarkan pada hasil pengamatan menunjukan bahwa ikan oskar di waduk Ir. H. Djuanda merupakan ikan omnivora yang memanfaatkan tumbuhan dan ikan sebagai pakan utamanya, larva serangga, dan fitoplankton sebagai pakan tambahan, serta serangga, detritus dan zooplankton sebagai pakan pelengkap (Gambar 2). Gambar 2 juga menunjukan bahwa kebiasaan makanan ikan ini pada bulan Maret, Mei, Agustus, Oktober, dan Desember selalu berubahubah. Hal tersebut diduga disebabkan kelimpahan makanan yang berbeda-beda dan kemudahan untuk mendapatkan mangsanya. Kebiasaan makanan ikan sangat dinamis dan ikan ini termasuk kelompok omnivora-karnivora, di mana pada bulan Mei dan Desember (saat tinggi muka air maksimal dan minimal) ikan oskar memanfaatkan ikan sebagai makanan utamanya (Gambar 2). Pada bulan Maret ikan ini banyak mengkonsumsi tumbuhan (makanan utama) dengan makanan pelengkapnya berupa ikan dan larva serangga, tetapi pada bulan Agustus, makanan utamanya bergeser menjadi larva serangga dan tumbuhan. Sedangkan pada bulan Oktober makan utama ikan ini berganti menjadi serangga. Kedinamisan kebiasaan makanan ikan oskar ini merupakan salah satu strategi dalam memanfaatkan sediaan sumber daya makanan, sehingga ikan ini mampu mendominansi perairan Waduk Ir. H. Djuanda. Hal tersebut sesuai dengan pendapat Cowx (1994) mengatakan bahwa makanan merupakan kunci pokok bagi pertumbuhan dan kelangsungan hidup ikan. Selanjutnya Nikolsky (1963) mengatakan bahwa kekurangan makanan merupakan faktor pembatas bagi perkembangan populasi ikan di perairan.

Hasil analisis pakan ikan tersebut sesuai dengan hasil penelitian Froese \& Pauly (2006); Kartamihardja (2007) mengatakan bahwa ikan oskar memanfaatkan tumbuhan, moluska, dan ikan, oleh karena itu ikan oskar termasuk ikan karnivora yang memanfaatkan ikan sebagai pakan utamanya (Anonimus, 2007).

Ikan oskar di Waduk Ir. H. Djuanda mempunyai luas relung pakan dan ruang serta distribusi yang luas (Anonimus, 2007). Di samping itu, ikan oskar yang mampu memanfaatkan fluktuasi kesediaan makan dan mempunyai kemampuan memijah sepanjang tahun. Ketersediaan pakan cukup tersedia untuk perkembangan dan pertumbuhan ikan oskar tersebut. $\mathrm{Hal}$ ini diduga berpengaruh positif terhadap pertumbuhan dan perkembangan ikan oskar, sehingga ikan tersebut dalam waktu relatif singkat mampu mendominansi perairan Waduk Ir. H. Djuanda.

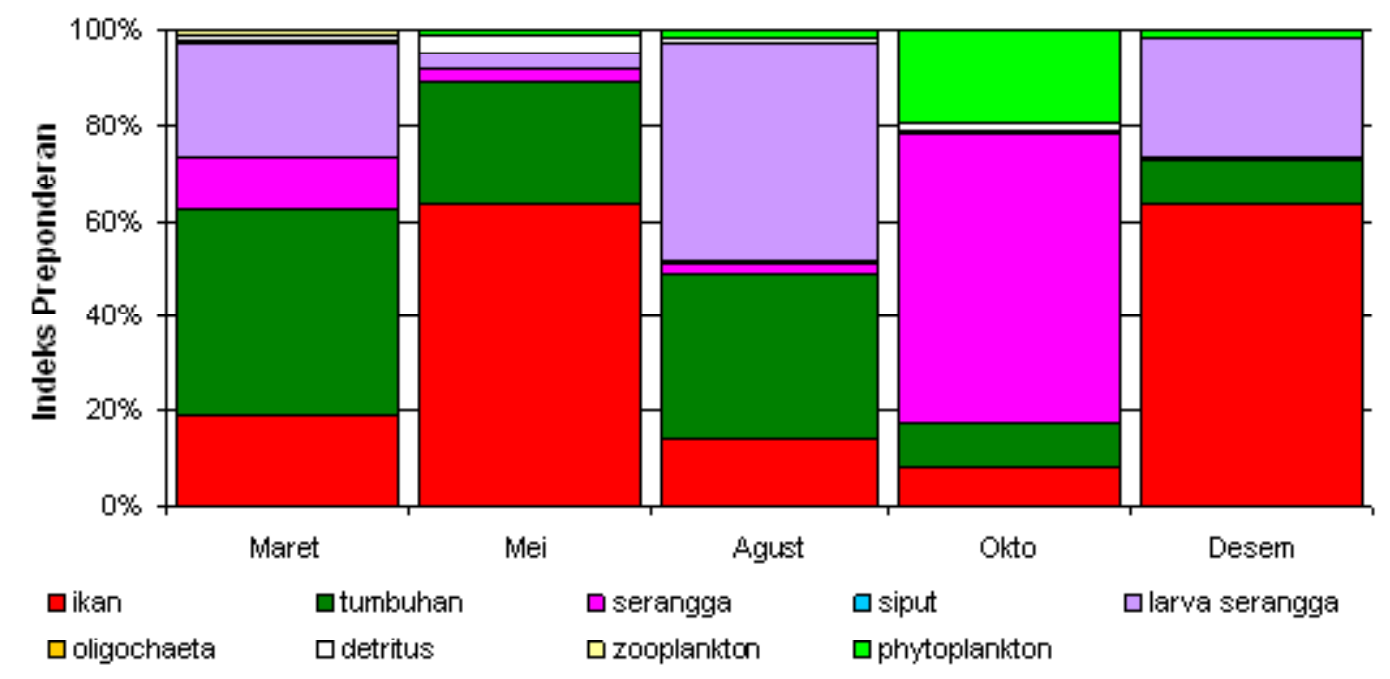

Gambar 2. Kebiasaan makanan ikan oskar.

Figure 2. Food habit of oscar. 


\section{Hubungan Panjang-Bobot Ikan}

Pertumbuhan merupakan suatu proses yang terjadi di dalam tubuh organisme yang menyebabkan perubahan ukuran panjang dan bobot tubuh dalam periode waktu tertentu. Pertumbuhan merupakan proses gabungan dari tingkah laku dan proses fisiologi. Menurut Sukimin et al. (2002), pertumbuhan ikan di suatu perairan banyak dipengaruhi oleh faktor lingkungan antara lain ukuran makanan yang dimakan, ukuran ikan di perairan, jenis makanan yang dimakan, serta kualitas lingkungan dan kondisi ikan (umur, keturunan, dan genetik).

Upaya mengevaluasi kesesuaian ikan oskar terhadap kesediaan makanan alami yang ada dapat menggunakan hubungan panjang-bobot ikan. Ikan oskar yang tertangkap berjumlah 393 ekor dan hasil regresi antara panjang-bobot ikan tersebut (Gambar 3), sebagai berikut:

$$
W=0,0036 L^{3,5705} \text { dengan } R^{2}=0,84
$$

Berdasarkan pada pengujian nilai b, diperoleh nilai $b \geq 3$ pada taraf 95 dan $99 \%$, sehingga dapat disimpulkan bahwa pertumbuhan ikan oskar adalah isometrik. Hal tersebut berarti ikan tersebut dapat tumbuh dengan baik dan tidak kekurangan pakan atau makanan yang dimanfaatkannya sesuai untuk ikan tersebut.

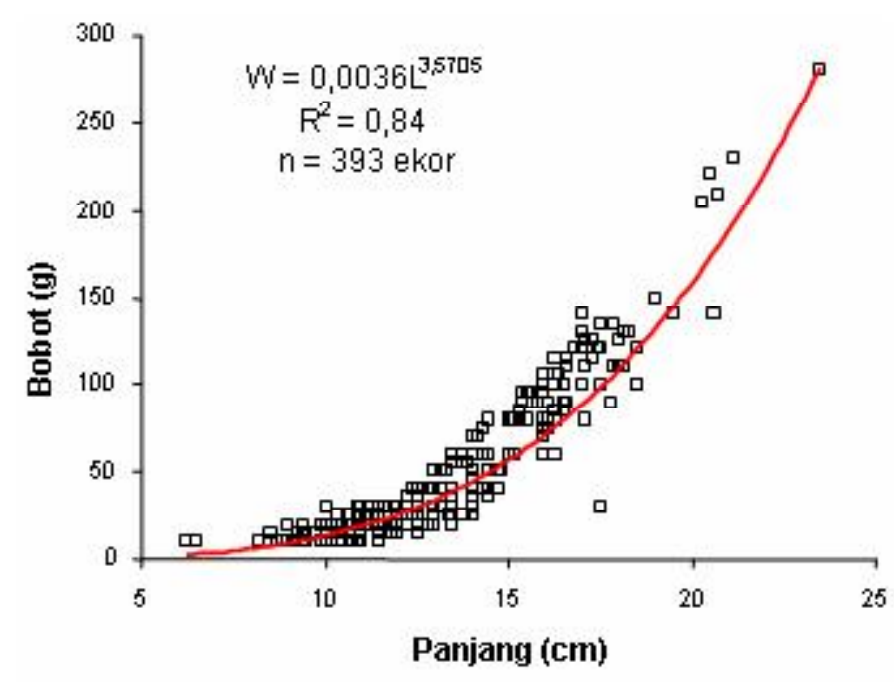

Gambar 3.

Figure 3.

Hubungan panjang-bobot ikan oskar.

Length-weight relationship of oskar.

\section{Tingkat Kematangan Gonad dan Indeks Kematangan Gonad}

Tingkat kematangan gonad berfungsi untuk mengetahui perbandingan antara gonad yang masak dengan stok yang ada di perairan, ukuran pemijahan, musim pemijahan, dan lama pemijahan dalam satu siklus (Sukimin et al., 2002). Fekunditas telur ikan oskar dilihat pada Tabel 2, di mana ikan oskar dengan kisaran panjang 12,1-14 cm mempunyai fekunditas rata-rata 1.878 butir, kisaran panjang 14,1-16 cm mempunyai fekunditas rata-rata 2.450 butir, kisaran panjang 16,1-18 cm mempunyai fekunditas rata-rata 2.629 butir, kisaran panjang 18,1-20 cm mempunyai fekunditas rata-rata 1.867 butir dan kisaran panjang 20,1-22 cm mempunyai fekunditas rata-rata 2.151 butir. Jadi dapat disimpulkan bahwa makin panjang ukuran ikan oskar menunjukan makin besar fekunditasnya (Gambar 4). 


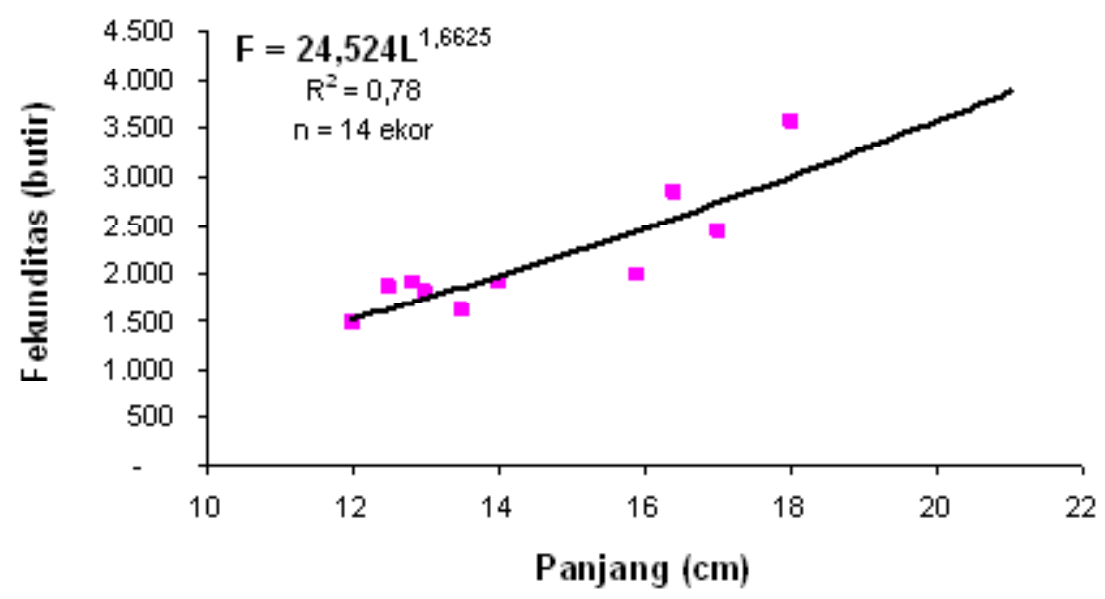

Gambar 4. Hubungan fekunditas dan panjang ikan oskar.

Figure 4. Fecundity and length relationship of oskar.

Berdasarkan pada Lampiran 1 dapat diketahui bahwa ikan oskar telah matang gonad dan siap untuk memijah dengan ukuran diameter telur berkisar antara 1,00-1,82 mm. Tingkat kematangan gonad IV ikan oskar selalu ditemukan setiap bulan pengamatan (bulan Maret, Juni, Agustus, dan Desember) (Lampiran 1). Kondisi tersebut menunjukan bahwa ikan oskar dapat memijah sepanjang tahun. Hal tersebut sesuai dengan pendapat beberapa ahli biologi ikan yang mengatakan bahwa ikan oskar dapat bertelur sepanjang tahun tanpa mengenal musim dan bertelur pada suhu hangat antara $24-28^{\circ} \mathrm{C}$ (Anonimus, 2007). Hal tersebut sesuai dengan suhu di Waduk Ir. $\mathrm{H}$. Djuanda yang berkisar $25,5-28^{\circ} \mathrm{C}$ (Anonimus, 2006).

Tabel 2. Fekunditas telur ikan oskar pada tingkat kematangan gonad IV menurut kelas ukuran Table 2. $\quad$ Egg fecundity of oskar in gonad maturity stage by size class

\begin{tabular}{cccc}
\hline Kisaran panjang $(\mathrm{cm})$ & \multicolumn{3}{c}{ Fekunditas (butir) } \\
\cline { 2 - 4 } & rata-rata & min & maks \\
\hline $12,1-14,0$ & 1.878 & 1.045 & 4.023 \\
$14,1-16,0$ & 2.450 & 1.561 & 4.435 \\
$16,1-18,0$ & 2.629 & 1.634 & 4.488 \\
$18,1-20,0$ & 1.867 & 1.553 & 2.199 \\
$20,1-22,0$ & 2.151 & 2.151 & 2.151 \\
\hline
\end{tabular}

Hubungan antara panjang total ikan dengan fekunditasnya mengikuti persamaan logaritma (Gambar 3), hal tersebut berarti makin panjang ukuran ikan mempunyai fekunditas makin besar. Jumlah telur yang dihasilkan oleh ikan oskar tersebut relatif sama dengan yang disampaikan dari Wikipedia bahwa ikan oskar bertelur 1.000 butir (Anonimus, 2007). Ikan oskar betina akan mengerami telurnya selama enam hari, walaupun kadang-kadang terjadi kerusakan telurnya (Anonimus, 2007).

\section{KESIMPULAN}

1. Ikan oskar termasuk golongan ikan omnivorakarnivora di mana makanan utamanya adalah ikan dan tumbuhan.
2. Laju pertumbuhan bobot dan panjang ikan oskar relatif seimbang sehingga mempunyai laju pertumbuhan yang isometrik.

3. Fekunditas ikan oskar yang mempunyai panjang antara $12-21 \mathrm{~cm}$ dengan bobot antara $15-210 \mathrm{~g}$ mempunyai fekunditas $1.595-3.567$ butir. Ikan ini memijah sepanjang tahun.

\section{PERSANTUNAN}

Tulisan ini merupakan kontribusi dari kegiatan riset monitoring biolimnologi Waduk Ir. H. Djuanda, Jawa Barat, T. A. 2006, di Loka Riset Pemacuan Stok IkanJatiluhur, Purwakarta. 
Beberapa Aspek Biologi Ikan ..... Ir. H. Djuanda, Jatiluhur, Jawa Barat (Purnamaningtyas, S.E. \& D.W.H. Tjahjo)

\section{DAFTAR PUSTAKA}

Anonimus. 2006. Laporan Akhir Riset Monitoring Sumber Daya Perikanan Waduk Ir. H.Djuanda. Loka Riset Pemacuan Stok Ikan. Badan Riset Kelautan dan Perikanan. 68 pp. (Tidak dipublikasikan).

Anonimus. 2007. Amphilophus citrinellus. Diambil darihttp://en.wikipedia.org/wiki/ Amphilophus_citrinellusTanggal 4 Desember 2007.

Beckman, W. C. 1962. The Freshwater Fishes of Siria and their General Biology and Management. Technical Paper. FAO. Rome. 297 pp.

Cowx, L. G. 1994. Stocking strategy. Fisheries Management and Ecology. 1: 15-30.

Edmonson, W. T. 1959. Freshwater Biology. $2^{\text {nd }}$ Ed. John Wiley \& Sons. Inc. New York. 1.248 pp.

Effendie, M. I. 1979. Metode Biologi Perikanan. Yayasan Dewi Sri. Bogor. 112 pp.

Froese, R. \& D. Pauly (eds). 2006. Fish Base. World Wide Web Electronic Publication.

Kartamihardja, E. S. 2007. Spektra ukuran biomassa plankton dan potensi pemanfaatannya bagi komunitas ikan di zona limnetik Waduk Ir. $\mathrm{H}$. Djuanda, Jawa Barat. Disertasi. Sekolah Pasca Sarjana Institut Pertanian Bogor. Bogor. 137 pp.
Loka Riset Pemacuan Stok Ikan. 2007. Laporan Akhir Riset Monitoring Sumber Daya Perikanan di Waduk Kaskade Sungai Citarum, Jawa Barat. Loka Riset Pemacuan Stok Ikan. Badan Riset Kelautan dan Perikanan. 40 pp. (Tidak dipublikasikan).

Macpherson, E. 1981. Resource partitioning in mediteranian demersal fish community. Mar. Ecol. Prog. Ser. 4: 183-193.

Nikolsky, G. V. 1963. The Ecology of Fishes. Transleted by. L. Brikett. Academy Press. London. $352 \mathrm{pp}$.

Needham, J. G. \& P. R. Needham. 1963. A Guide to the Study of Freshwater Biology. Fifth edition. Revused and Enlarged. Holden Day Inc. San Francisco. 180 pp.

Purnamaningtyas, S. E. \& D. W. H. Tjahjo. 2007. Inventarisasi ikan hias di Waduk Ir. H. Djuanda dan Waduk Cirata, Jawa Barat. Ikan Hias Nusantara. Pusat Riset Perikanan Budi Daya. Badan Riset kelautan dan Perikanan. Departemen Kelautan dan Perikanan. 95-102.

Sukimin, S., S. Isdrajat, \& Y. Vitner. 2002. Petunjuk Praktikum Biologi Perikanan. Fakultas Perikanan dan IImu Kelautan. Institut Pertanian Bogor. Bogor. 


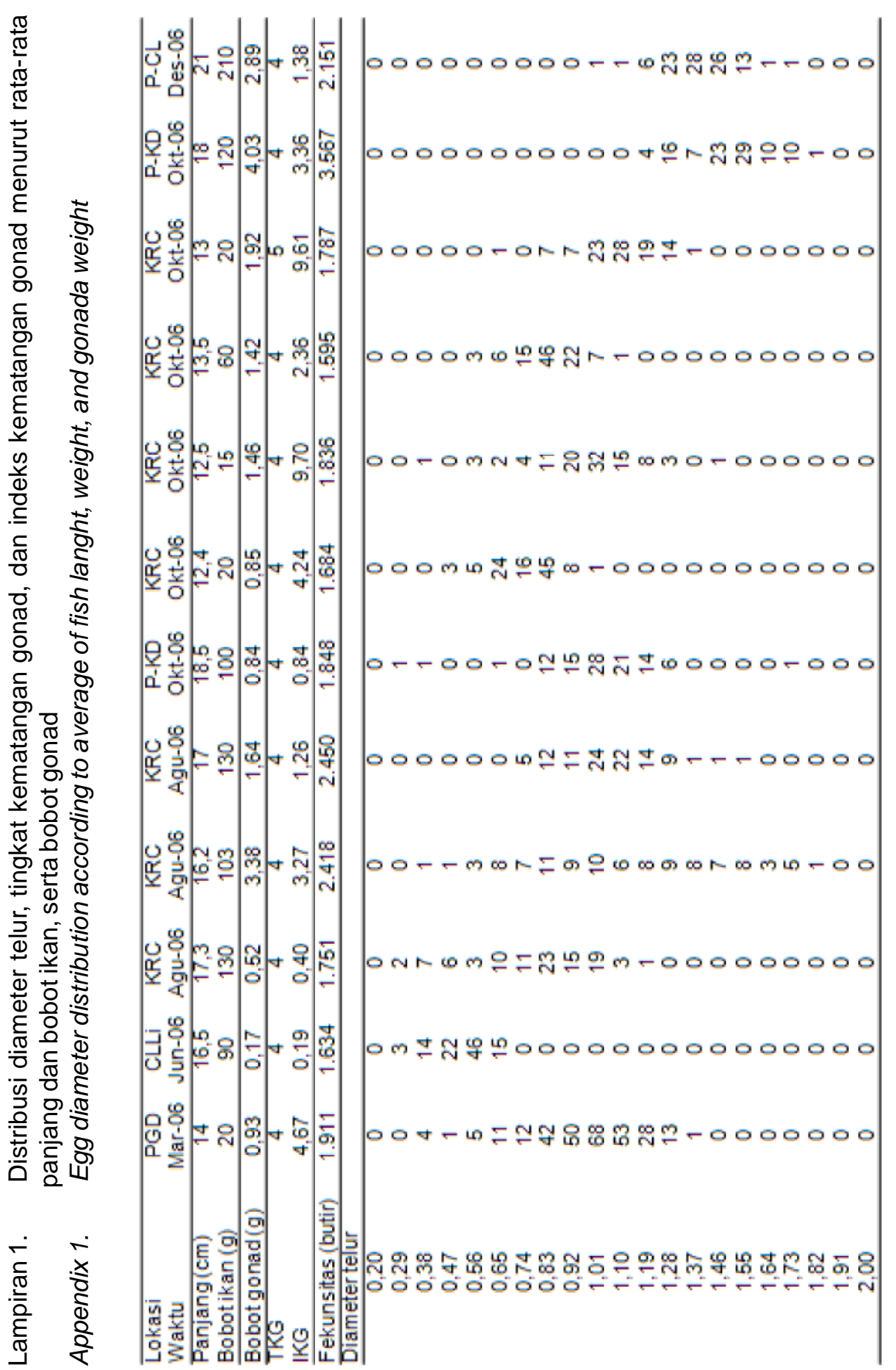

